\title{
Medical student reflections on interprofessional education
}

This article was published in the following Dove Press journal:

Advances in Medical Education and Practice

\section{Mohamad Zeina \\ Annabel Elizabeth Jones \\ Roxanna Colebatch \\ GKT School of Medical Education, King's College London, London, UK}

Correspondence: Mohamad Zeina GKT School of Medical Education, King's College London, Hodgkin Building, Newcomen Street, London SEI IUL, UK Tel +442071887188

Email mohamad.zeina@kcl.ac.uk

\section{Dear editor}

We thank Safabakhsh et al $^{1}$ for their thought-provoking article on interprofessional education (IPE), a topic that we do not believe receives enough attention in medical literature. As medical students who have recently undertaken an IPE module at King's College London, we believe we are well placed to comment on this paper and how it relates to our experiences at medical school. We wholeheartedly agree with Safabakhsh et al's ${ }^{1}$ idea that good IPE is essential for patient care and that a clear framework, such as that set out in the paper, can help achieve this.

However, we disagree with one phrase in particular from the original article: that if team members "know their responsibilities well, they [can] make fewer mistakes than others." We believe this misses the point of teamwork, and makes it seem like the goal is to avoid individual blame rather than work together to ensure the best possible level of care for the patient. The "Swiss cheese model" was built to highlight this idea that individual mistakes are inevitable, ${ }^{2}$ and the only way to avoid poor patient outcomes is for each individual to know how they fit into the bigger picture so that individual mistakes are compensated for. We must be careful to ensure that our attitudes do not encourage defensive practice, and instead promote a multidisciplinary approach to avoiding errors.

In our experience, engaging in IPE workshops - rather than just attending - has helped us to envision ourselves as part of the bigger picture, thereby helping us to identify weaknesses within the system as well as potential ways to improve our team communication. Seeing ourselves as part of the team has also made these exercises much more motivating and stimulating. This is especially important given that a review found low motivation to be one of the four factors that contribute to low empathy during medical school. ${ }^{3}$

IPE is a vital piece of the curriculum that unfortunately does not get much attention at medical school, often resulting in an unstructured approach. We hope that more frameworks, such as that presented in the article by Safabakhsh et al, ${ }^{1}$ encourages a more systematic approach to IPE so that more of us can act as productive members of the team for the benefit of the patient.

\section{Disclosure}

The authors report no conflicts of interest in this communication. 


\section{References}

1. Safabakhsh L, Irajpour A, Yamani N. Designing and developing a continuing interprofessional education model. Adv Med Educ Pract. 2018;9:459-467.
2. Reason J. The contribution of latent human failures to the breakdown of complex systems. Philos Trans R Soc Lond B Biol Sci. 1990;327(1241):475-484.

3. Stepien KA, Baernstein A. Educating for empathy. J Gen Intern Med. 2006;21(5):524-530.

Dove Medical Press encourages responsible, free and frank academic debate. The content of the Advances in Medical Education and Practice 'letters to the editor' section does not necessarily represent the views of Dove Medical Press, its officers, agents, employees, related entities or the Advances in Medical Education and Practice editors. While all reasonable steps have been taken to confirm the content of each letter, Dove Medical Press accepts no liability in respect of the content of any letter, nor is it responsible for the content and accuracy of any letter to the editor.

Advances in Medical Education and Practice

Dovepress

\section{Publish your work in this journal}

Advances in Medical Education and Practice is an international, peerreviewed, open access journal that aims to present and publish research on Medical Education covering medical, dental, nursing and allied health care professional education. The journal covers undergraduate education, postgraduate training and continuing medical education including emerging trends and innovative models linking education, research, and health care services. The manuscript management system is completely online and includes a very quick and fair peer-review system. Visit http://www.dovepress.com/testimonials.php to read real quotes from published authors.

Submit your manuscript here: http://www.dovepress.com/advances-in-medical-education-and-practice-journal 